\title{
Penetration of Intact Mitochondria by Dehydroepiandrosterone and its Conjugates or Derivatives
}

The permeability of biological membranes is known to represent a major factor in the in-vivo metabolism of any compound. Previous investigations, therefore, were concerned with the penetration of intact human erythrocytes by steroid or steroid conjugates and the subsequent inhibition of intracellular glucose-6-phosphate dehydrogenase $^{1}$. In continuation of such experiments, the penetration of intact mitochondria by dehydroepiandrosterone (3 $\beta$-hydroxy-5-androsten-17-one, DHEA) and its conjugates or derivatives was studied.

Liver tissue from male guinea-pigs (Pirbright white) was homogenized in $5 \mathrm{ml} 0.25 \mathrm{M}$ sucrose per $\mathrm{g}$ of wet tissue, employing a Potter-Elvehjem glas homogenizer. Following a $10 \mathrm{~min}$ centrifugation at $900 \mathrm{~g}$, the supernatant was removed and centrifuged for $20 \mathrm{~min}$ at $13,000 \mathrm{~g}$. Precipitated mitochondria were washed twice with $0.15 M$ phosphate buffer of $\mathrm{pH} \mathrm{7.4,} \mathrm{the} \mathrm{suspension} \mathrm{being} \mathrm{centri-}$ fuged for $20 \mathrm{~min}$ at $15,000 \mathrm{~g}$. The final precipitate was resuspended in $1 \mathrm{ml}$ of $0.2 M$ Tris buffer of $\mathrm{pH} 7.4$ per $\mathrm{g}$ of original weight of wet tissue. To $0.5 \mathrm{ml}$ of this suspension $2.5 \mathrm{ml}$ of the Tris buffer and $0.02 \mathrm{ml}$ dioxane with steroid or steroid derivative were added. The final concentration us steroidal compounds corresponded to a $10^{-4} M$ solution. The various ${ }^{3} \mathrm{H}$-labelled substrates with 44,600 to 899,000 $\mathrm{cpm}{ }^{3} \mathrm{H}$ are listed in Table I. After incubation for $30 \mathrm{~min}$ at $37^{\circ} \mathrm{C}$ under continuous shaking, the mitochondria were separated again by centrifugation for $20 \mathrm{~min}$ at $15,000 \mathrm{~g}$ and washed twice, using $3.0 \mathrm{ml} 0.15 \mathrm{M}$ phosphate buffer of $\mathrm{pH} 7.4$ per washing. The washed mitochondria were suspended in water and homogenized in the Ultra-Turrax (JANke and Kunkel, Staufen). In the homogenates ${ }^{3} \mathrm{H}-$ labelled compounds were determined by standard procedures ${ }^{2}$.

As can be derived from Table I, substantial amounts of free DHEA and DHEA sulfatide had entered the mitochondria, whereas little more than $8 \%$ of ${ }^{3} \mathrm{H}$-activity were detected in mitochondria following the incubation with DHEA sulfate. Since in the latter experiment practically all ${ }^{3} \mathrm{H}$-activity was associated with the fraction of lipophile steroid sulfatide, it may be assumed that a partial conversion of the hydrophile steroid sulfate to the lipophile steroid sulfatide ${ }^{3}$ was responsible for the penetration of incubated mitochondria labelled compounds. Such a conclusion is supported by the failure of 2 other water-soluble conjugates, namely DHEA phosphate and DHEA glucuronoside, to penetrate the mitochondrial membrane. Furthermore, after incubation of intact human erythrocytes with ${ }^{3} \mathrm{H}$-labelled DHEA sulfate, phosphate or glucuronoside no ${ }^{3} \mathrm{H}$-activity had been found in the hemolysates ${ }^{1}$. The permeability of biological membranes for steroids or steroid conjugates

Table I. Penetration of intact mitochondria from guinea-pig liver by $7 \alpha^{-3} \mathrm{H}$-DHEA, its conjugates or derivatives

\begin{tabular}{lll}
\hline $\begin{array}{l}\text { Compound } \\
\left(10^{-4} M\right)\end{array}$ & $\begin{array}{l}{ }^{3} \mathrm{H} \text {-activity } \\
\text { in mitochondria } \\
(\%)\end{array}$ \\
\hline $7 \alpha^{-3} \mathrm{H}-\mathrm{DHEA}$ & & 20.6 \\
& -sulfate & 8.1 \\
& -phosphate & 0.1 \\
& -glucuronoside & $<0.1$ \\
& -sulfatide & 53.2 \\
& -acetate & 20.1 \\
& -caproate & 28.4 \\
& -laurate & 34.7 \\
- -stearate & 40.2 \\
\hline
\end{tabular}

Table II. Metabolism of $7 \alpha-{ }^{3} \mathrm{H}-\mathrm{DHEA}, 7 \alpha-{ }^{8} \mathrm{H}-\mathrm{DHEA}$ sulfate and $7 \alpha^{-3} \mathrm{H}-\mathrm{DHEA}$ sulfatide in intact mitochondria

\begin{tabular}{|c|c|c|c|}
\hline \multirow[t]{2}{*}{ Steroid } & \multicolumn{3}{|c|}{$\begin{array}{l}\text { nMoles/mitochondria equiv. to } \\
0.5 \mathrm{~g} \text { wet tissue after incuba- } \\
\text { tion in } 3.0 \mathrm{ml} \text { of a } 10^{-4} M \\
\text { solution of }\end{array}$} \\
\hline & DHEA & $\begin{array}{l}\text { DHEA } \\
\text { sulfate }\end{array}$ & $\begin{array}{l}\text { DHEA } \\
\text { sulfatide }\end{array}$ \\
\hline Dehydroepiandrosterone & 43.5 & 17.8 & 110.8 \\
\hline Androstenediol & 6.9 & 2.1 & 17.4 \\
\hline 16-OH-dehydroepiandrosterone & 2.4 & 1.2 & 6.0 \\
\hline Androstenetriol & 3.3 & 1.6 & 18.3 \\
\hline Androstenedione & 1.2 & 1. & 3.9 \\
\hline Androsterone & 1 & 1 & 1.5 \\
\hline Etiocholanolone & 1 & 1 & 1.8 \\
\hline
\end{tabular}

obviously depends on the lipophile properties of the particular compound. This may be deduced from the remarkable penetration of mitochondria by DHEA alkylates, the percentage of ${ }^{3} \mathrm{H}$-activity in their homogenates increasing with the chain length of the esterifying alkanoic acid.

Concerning the metabolism of some of the substrates, minor but significant amounts of well-known metabolites were isolated from the homogenates of incubated mitochondria. Androstenediol (5-androstene$3 \beta, 17 \beta$-diol), androstenetriol (5-androstene- $3 \beta, 16 \alpha, 17 \beta$ triol), 16-OH-DHEA $(3 \beta, 16 \alpha$-dihydroxy-5-androsten-17one) and androstenedione (4-androstene-3,17-dione) turned out to be the predominant metabolites of DHEA and DHEA sulfatide and accounted for $11.9 \%$ and $16.1 \%$ resp. of intramitochondrial, ${ }^{3} \mathrm{H}$-labelled steroids. Their identification was based upon the chromatographic purification of free compounds and suitable derivatives to constant specific activity. Of the various enzyme systems involved in the formation of these metabolites so far only the $17 \beta$-hydroxy steroid oxido-reductase has been demonstrated in mitochondria from guinea-pig liver ${ }^{4}$, the other enzymes usually being allocated to the microsomal fraction ${ }^{5}$.

Zusammenfassung. Nach Bebrütung intakter Mitochondrien aus Meerschweinchenleber in $10^{-4} M$ Lösung von $7 \alpha^{-}{ }^{3} \mathrm{H}$-DHEA bzw. seinen Konjugaten oder Derivaten zeigte es sich, dass lediglich lipophile Verbindungen wie das freie Steroid, besonders aber DHEA-sulfatid, durch die Membran eingedrungen und metabolisiert worden waren.

\section{P. Benes, G. Herz and G. W. Oertel}

Abteilung für Experimentelle Endokrinologie,

Universitäts-Frauenklinik, Langenbeckstrasse 1,

D-65 Mainz (Germany), 21 September 1971.

1 P. Benes, R. Simsony and G. W. Oertel, Steroidologia, in press (1971).

a G. W. Oertel, P. Knapstein and I. Treiber, Hoppe-Seyler's Z. physiol. Chem. 345, 221 (1966).

3 G. W. Oertel and K. Groot, Hoppe-Seyler's Z. physiol. Chem. 341, 1 (1965).

4 G. L. Endahl and C. D. Kochakian, Biochim. biophys. Acta 62, 245 (1962).

5 R.I. Dorfman and F. UNGAR, Metabolism of Steroid Hormones (Academic Press, New York-London 1965). 